ZOOLOGIA 32 (4): 263-269, August 2015

http://dx.doi.org/10.1590/S1984-46702015000400001

\title{
Advertisement and release calls of Phyllomedusa ayeaye (Anura: Hylidae) with comments on the social context of emission
}

\author{
Renato C. Nali1,*, Marília M. Borges ${ }^{1} \&$ Cynthia P.A. Prado ${ }^{2}$
}

\author{
'Programa de Pós-graduação em Ciências Biológicas (Zoologia), Instituto de Biociências, Departamento de Zoologia, \\ Universidade Estadual Paulista "Júlio de Mesquita Filho". Rio Claro, SP, Brazil. \\ 2Departamento de Morfologia e Fisiologia Animal, Faculdade de Ciências Agrárias e Veterinárias, Universidade Estadual \\ Paulista "Júlio de Mesquita Filho". Jaboticabal, SP, Brazil. \\ *Corresponding author. E-mail: r_nali@yahoo.com.br
}

\begin{abstract}
Male calls play different roles in anuran social organization, such as spacing, territoriality and female attraction. However, calls and associated behaviors remain poorly described for many anuran species. Here we describe the advertisement and release calls of the tree frog Phyllomedusa ayeaye (Lutz, 1966) and report on the social context of emissions and a physical combat. Approximately 35 minutes of digital recordings were obtained from 34 hours of observations at one breeding site in the state of Minas Gerais, southeastern Brazil. Bioacoustic analysis showed that males emitted two types of advertisement calls: 1 ) simple call (a sequence of short pulsed notes) and 2) composite call (a sequence of short pulsed notes followed by a long pulsed note). Composite calls were emitted more frequently during more intense chorus activity, with various active males at the breeding site. The release call was also composed by short pulsed notes, with a wider spectrum of frequencies and emitted more rapidly than the advertisement calls. Our results suggest that the composite call of $P$. ayeaye may represent a mixed advertisement call. Long notes might be the aggressive part directed to males, whereas short notes directed to females. Our description of call types, their functions, and male physical interactions will be useful for studies investigating the systematics and behavior of Phyllomedusa species.
\end{abstract}

KEY WORDS. Aggressive behavior; bioacoustics; Cerrado; composite call; Phyllomedusinae.

Calling activity is one of the most remarkable topics in anuran behavior because of the complex vocal repertoire often found (WeLLs 2007). Males of a single species generally emit multiple types of call, with each type associated with a particular social role (Toledo et al. 2014, BRUNETTI et al. 2015). The opposite situation is also possible, in which a single call type may carry multiple messages, i.e., a mixed call (Wells 1988, Gerhardt 1992). For instance, the most studied of the reproductive calls, the advertisement call (Toledo et al. 2014), may attract females, warn conspecifics of the male's position, signal body size, and allow individual recognition (LESBARRÈrEs \& Lodé 2002, Nali \& Prado 2014a). Moreover, in species with extensive calling seasons, the advertisement call may stimulate the reproductive physiology of females, thereby maintaining their reproductive condition (LEA et al. 2001).

The release call is another type of reproductive call, and signals a lack of reproductive receptivity (Toledo et al. 2014). In general, anuran males emit release calls when mistakenly amplexed by other males during reproductive events (Wells 2007); however, they can also emit release calls during physically aggressive interactions (BASTOS \& HADDAD 1995, BRUNETTI et al. 2015). In some species, both males and non-receptive females may display release vibrations when amplexed by other males, rather than producing audible sounds (BOGERT 1960, Penna \& Veloso 1982). Release calls can be used as a diagnostic character in closely related species (Grenat \& Martino 2013). Moreover, it has been suggested that advertisement calls of frogs may have evolved from simple release calls (RAND 1988, SCHMIDT et. al. 1990). However, the scarcity of information on anuran release calls has precluded a phylogenetic analysis of this hypothesis (Wells 2007). Altogether, the description of both advertisement and release calls for anuran species is highly relevant (Grenat \& Martino 2013, Toledo et al. 2014).

Phyllomedusa currently includes 30 recognized species of tree frogs (Frost 2015). Phyllomedusa ayeaye (Lutz, 1966) belongs to the P. hypochondrialis group (sensu Faivovich et al. 2010) and was described from Morro do Ferro $\left(21^{\circ} 48^{\prime} \mathrm{S}, 46^{\circ} 35^{\prime} \mathrm{W}, 1,400-\right.$ 1,540 m elevation), municipality of Poços de Caldas, state of Minas Gerais, southeastern Brazil. This species occurs in the Atlantic forest and the adjacent Cerrado, which are among the most threatened formations in Brazil, and is consequently faced with major threats such as habitat loss caused by deforestation, fire, mining, and pollution (SiLVA \& Bates 2002, Ribeiro et al. 2009). Currently, there is a discrepancy in the conservation status of

2015 | Sociedade Brasileira de Zoologia | www.sbzoologia.org.br | www.scielo.br/zool All content of the journal, except where identified, is licensed under a Creative Commons attribution-type BY-NC. 
P. ayeaye, since it has been classified as Critically Endangered according to the International Union for Conservation of Nature - IUCN (CARAMASCHI et al. 2010), while it is no longer considered endangered by the new List of Threatened Species of the Brazilian Fauna (ICMBio 2014). Indeed, ecological niche modeling uncovered a theoretically broader geographical distribution for the species (Giovanelli et al. 2008). Additionally, P. itacolomi Caramaschi, Cruz \& Feio, 2006 and $P$. ayeaye were synonymized based on morphology, which expanded the distribution area of P. ayeaye (BAÊTA et al. 2009). However, little is known about the natural history of this species, including calling behavior and repertoire, precluding inference on the actual population status. In the present study, we describe the advertisement and release calls of $P$. ayeaye and report on a male-male fight and social functions of the different notes.

\section{MATERIAL AND METHODS}

The current study was conducted in the municipality of Sacramento, Minas Gerais state, southeastern Brazil, in the Cerrado of the Serra da Canastra mountain range. The region is characterized by a markedly seasonal regime, with a dry winter (April-September) and a hot and rainy summer (OctoberMarch). The topography is mountainous (up to $1,500 \mathrm{~m}$ elevation), with deep valleys and many streams, and the landscape is composed of savannas, grassland fields, gallery forests alongside streams, and small regions of semi-deciduous forest (DieTz 1984). Individuals of $P$. ayeaye were active in a pond associated with a temporary stream $\left(20^{\circ} 13^{\prime} 09.9^{\prime \prime} \mathrm{S}, 47^{\circ} 06^{\prime} 21^{\prime \prime} \mathrm{W}\right.$, $880 \mathrm{~m}$ elevation), distant ca. $180 \mathrm{~km}$ in a straight line from the type locality.

Fieldwork was conducted from October 2010 to January 2011, and during February 2014, obtaining approximately 35 minutes of digital recordings from 34 hours of direct observations. During the night at the breeding site, males were located by their calls, and observed to investigate social functions of the calls emitted. Six males were collected, anesthetized with $10 \%$ lidocaine, fixed in 10\% formalin, preserved in $70 \%$ ethanol (McDiarmid 1994), and deposited at Coleção de Anfíbios Célio F.B. Haddad, Departamento de Zoologia, I.B., Universidade Estadual Paulista, Rio Claro, SP, Brazil (voucher numbers: CFBH32772-32775, CFBH32777, CFBH32779). Body sizes (snoutvent length, SVL) of these six specimens as well as five other males captured and released in the same field were measured with a digital caliper to the nearest $0.01 \mathrm{~mm}$. Air temperature was measured every night with a digital thermo-hygrometer to the nearest $0.1^{\circ} \mathrm{C}$.

For the recordings, we used a Marantz Professional PMD660 digital recorder, with a unidirectional microphone Sennheiser ME66. Bioacoustic analyses were conducted using the software Raven Pro 1.3 (Cornell Lab of Ornithology), at 16 bit resolution and 44,100 $\mathrm{Hz}$ sampling rate, using FFT $=512$ (Fast Fourier Transformation). Short notes of the simple call, short notes of the composite call, and long notes were analyzed separately. We gently simulated an axillary amplexus, characteristic of the species (R.C. NALI pers. obs.), to record the release calls of each male either in the field on the same night or in the laboratory the day after male collection. We adopted the following terminology (adapted from MarTINS \& JIM 2003, Toledo et al. 2014): 1) call: a sequence of sounds produced and emitted in a temporal pattern; 2) note: temporally discrete vocalization units composing the call; and (3) pulse: subdivision of the note in smaller temporal units. We measured the following bioacoustic variables: number of short notes emitted in sequence, number of pulses/note, note duration (s), interval between notes (s), and minimum, maximum, and dominant frequencies $(\mathrm{Hz})$. We then tested for statistical differences between the variables of the short notes of the simple and composite calls using Student's t-tests (ZAR 1999).

Additionally, to evaluate male aggressive responses, we acoustically and visually stimulated resident males. The acoustic stimulus was a recording in WAV format (approximately one minute), containing four simple advertisement calls with an average of nine short notes emitted in sequence (air temperature of recording $=21.8^{\circ} \mathrm{C}$ ). This recording was broadcasted to a resident calling male at a distance of $40 \mathrm{~cm}$, using a digital recorder connected to a mini-speaker. The visual stimulus consisted of placing an intruder male ca. $15 \mathrm{~cm}$ away from a resident male; in this case, a video was recorded using a Canon 7 digital camera.

\section{RESULTS}

Males of $P$. ayeaye had an average SVL of $33.17 \pm 1.94 \mathrm{~mm}$ (31.28-36.6 mm; $\mathrm{N}=11$ ), and mostly called from leaves and branches of small trees and bushes surrounding the stream, about 1.5 to $2 \mathrm{~m}$ above water or ground. We recorded the advertisement calls of two collected males $\left(10^{\text {th }}\right.$ October 2010 , air temperature $=18.5^{\circ} \mathrm{C} ; 15^{\text {th }}$ December 2010 , air temperature $=$ $\left.21.4^{\circ} \mathrm{C}\right)$, and four uncollected males $\left(17^{\text {th }}\right.$ November 2010 , air temperature $=22.2^{\circ} \mathrm{C} ; 19^{\text {th }}$ February 2014 , air temperature $=$ $23.5^{\circ} \mathrm{C}$ ). Males of $P$. ayeaye emitted 1 ) simple advertisement calls with an average of six short pulsed notes, or 2) composite advertisement calls with a sequence of an average of six short pulsed notes followed by one long pulsed note (Figs 1-2, Table 1). The composite calls were more frequently emitted during more intense chorus activity, with various active males at the breeding site. Short notes of the simple call were statistically different from those of the composite call regarding $\mathrm{N}$ pulses/note (Student's $\left.\mathrm{t}_{116}=9.1, \mathrm{p}<0.001\right)$, note duration $\left(\mathrm{t}_{131}\right.$ $=3.8, \mathrm{p}<0.001)$, maximum frequency $\left(\mathrm{t}_{112}=16.9, \mathrm{p}<0.001\right)$, minimum frequency $\left(\mathrm{t}_{112}=7.3, \mathrm{p}<0.001\right)$, and dominant frequency $\left(\mathrm{t}_{112}=5.2, \mathrm{p}<0.001\right.$; Table 1$)$. On the other hand, the two types of short notes were similar regarding $\mathrm{N}$ notes emitted in sequence $\left(\mathrm{t}_{44}=0.7, \mathrm{p}=0.49\right)$ and interval between notes $\left(\mathrm{t}_{121}=1.4, \mathrm{p}=0.16\right.$; Table 1$)$. 

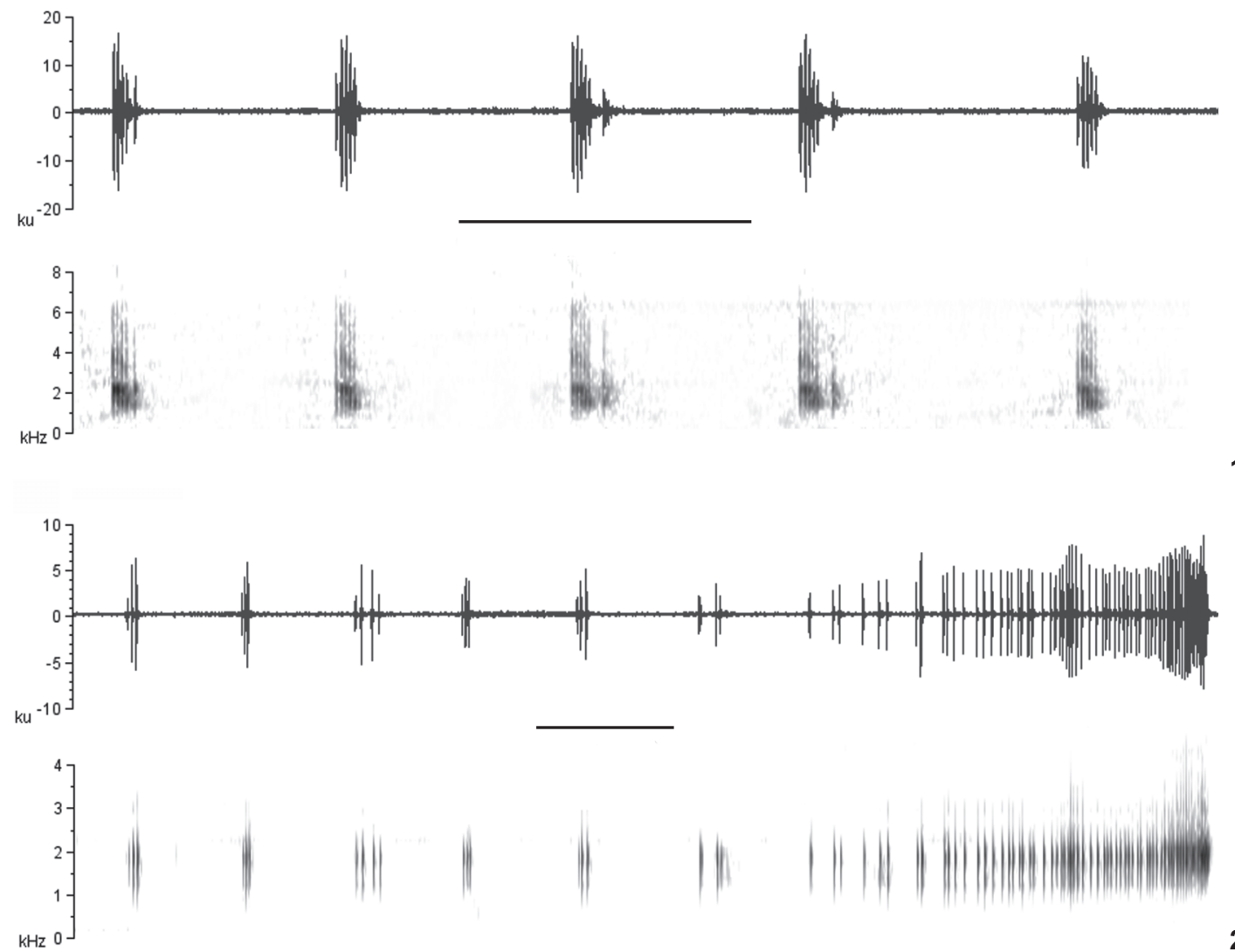

Figures 1-2. The two types of advertisement calls emitted by males of Phyllomedusa ayeaye, municipality of Sacramento, southeastern Brazil: (1) simple advertisement call, with only short notes (voucher specimen $=\mathrm{CFBH} 32772, \mathrm{SVL}=31.84 \mathrm{~mm}$, air temperature $=18.5^{\circ} \mathrm{C}$ ); (2) composite advertisement call, with six short notes followed by one long note (unvouchered male, air temperature $=22.2^{\circ} \mathrm{C}$ ). For each call, we show the oscillogram reading above and the spectrogram below (FFT $=256$, contrast $=70$, and brightness $=70)$. Scale bars: $0.5 \mathrm{~s}$.

We recorded the release calls of five collected males (14$15^{\text {th }}$ November 2010, air temperature $=23^{\circ} \mathrm{C} ; 17^{\text {th }}$ January 2011, air temperature $\left.=21^{\circ} \mathrm{C}\right)$, and one uncollected male $\left(10^{\text {th }}\right.$ October 2010, air temperature $=18.5^{\circ} \mathrm{C}$ ). The release call of $P$. ayeaye was also composed of short pulsed notes, but somewhat different from the short notes of the advertisement call (Fig. 3, Table 2). For example, the mean interval between the short notes of the advertisement calls was approximately three-fold longer than that of the short notes of the release call. In general, spectral variables of the release calls varied to a greater degree and showed a wider spectrum of frequencies than the advertisement calls. We did not count the number of short notes emitted in sequence for the release calls, because this depended on how long the male was stimulated. This type of call was audibly more vigorous than the short notes of the advertisement calls.

We concentrated on behavioral observations on $18^{\text {th }}$ February 2014 (air temperature $=23.2^{\circ} \mathrm{C}$ ). We observed a fight already in progress between two uncollected males (SVLs $=36.6$ and $33.1 \mathrm{~mm}$, Fig. 4). At 9:26 pm, the two fighting males were found hanging from a branch and holding each other, remaining still for seven minutes. Subsequently, one of the males started moving toward a nearby branch, and two minutes after reaching this branch with its front limbs, it managed to escape from the opponent. No calls were emitted during the time we observed the fight. The acoustic stimulation of one resident calling male (SVL $=35 \mathrm{~mm}$ ) triggered an aggressive response in which the individual moved toward the speaker and responded vigorously with short notes followed by long notes (composite call). When we visually stimulated a resident male $(\mathrm{SVL}=36.38)$ by placing another male $(\mathrm{SVL}=33.2 \mathrm{~mm})$ on the same branch, they started moving around the branches, first quietly, then calling aggressively to each other, using the composite call. No physical interactions were observed at this time, but males emitted approximately three short notes followed by a long note, rather than six short notes followed by a long note (Table 1). Similar acoustic aggressive interactions were observed under natural conditions in which two males called vigorously to each other using both short and long notes. 
Table 1. Acoustic variables of the simple and composite advertisement calls of Phyllomedusa ayeaye, Sacramento, Minas Gerais, Brazil. Statistically different variables are shown in bold (see text for details). N: sample size; SD: standard deviation.

\begin{tabular}{|c|c|c|c|c|c|}
\hline & Mode & Mean & SD & Range & $\mathrm{N}$ \\
\hline \multicolumn{6}{|l|}{ Short notes of the simple call } \\
\hline $\mathrm{N}$ notes emitted in sequence & 5 & 5.7 & 2.6 & $2-11$ & 33 \\
\hline $\mathrm{N}$ pulses/note & 7 & 6.3 & 1.5 & $3-11$ & 78 \\
\hline Minimum frequency $(\mathrm{Hz})$ & 995.1 & 917.1 & 174.3 & $464.4-1,209.2$ & 82 \\
\hline Maximum frequency $(\mathrm{Hz})$ & $4,858.7$ & $5,865.5$ & 807.4 & $4,450.3-7,609.8$ & 82 \\
\hline Dominant frequency $(\mathrm{Hz})$ & $1,894.9$ & $1,986.3$ & 145.4 & $1,636.5-2,239.5$ & 82 \\
\hline Note duration (s) & 0.068 & 0.080 & 0.021 & $0.045-0.132$ & 101 \\
\hline Interval between notes (s) & 0.442 & 0.388 & 0.075 & $0.279-0.674$ & 76 \\
\hline \multicolumn{6}{|l|}{ Short notes of the composite call } \\
\hline $\mathrm{N}$ notes emitted in sequence & 7 & 6.3 & 3.4 & $2-13$ & 13 \\
\hline N pulses/note & 3 & 3.9 & 1.0 & $3-6$ & 40 \\
\hline Minimum frequency $(\mathrm{Hz})$ & 612.8 & 676.1 & 108.6 & $459.7-919.3$ & 32 \\
\hline Maximum frequency $(\mathrm{Hz})$ & $3,370.7$ & $3,379.1$ & 285.1 & $2,922.4-4,119.7$ & 32 \\
\hline Dominant frequency $(\mathrm{Hz})$ & $1,808.8$ & $1,849.2$ & 48.8 & $1,808.8-1,981.1$ & 32 \\
\hline Note duration (s) & 0.055 & 0.064 & 0.022 & $0.043-0.121$ & 32 \\
\hline Interval between notes (s) & 0.302 & 0.367 & 0.084 & $0.244-0.710$ & 47 \\
\hline \multicolumn{6}{|l|}{ Long notes of the composite call } \\
\hline $\mathrm{N}$ pulses/note & 74.0 & 69.2 & 14.2 & $48-84$ & 16 \\
\hline Minimum frequency $(\mathrm{Hz})$ & 830.3 & 765.9 & 69.9 & $649.8-899.5$ & 16 \\
\hline Maximum frequency $(\mathrm{Hz})$ & $4,428.5$ & $4,144.0$ & 300.1 & $3,820-5,051.3$ & 16 \\
\hline Dominant frequency $(\mathrm{Hz})$ & $1,894.9$ & $1,890.6$ & 109.9 & $1,722.7-2,239.5$ & 20 \\
\hline Note duration (s) & - & 1.198 & 0.323 & $0.655-1.747$ & 23 \\
\hline
\end{tabular}

Table 2. Acoustic variables of the release call of Phyllomedusa ayeaye, Sacramento, Minas Gerais, Brazil.

\begin{tabular}{lccccc}
\hline & Mode & Mean & SD & Range & N \\
\hline N pulses/note & 9 & 9.5 & 2.7 & $5-17$ & 108 \\
Minimum frequency $(\mathrm{Hz})$ & 490.0 & 501.5 & 113.9 & $294.0-895.1$ & 113 \\
Maximum frequency $(\mathrm{Hz})$ & $7,301.0$ & $8,433.2$ & $1,806.9$ & $4,668.5-11,946.9$ & 113 \\
Dominant frequency $(\mathrm{Hz})$ & $1,550.4$ & $1,651.8$ & 612.9 & $861.3-4,651.2$ & 113 \\
Note duration (s) & 0.050 & 0.051 & 0.008 & $0.031-0.072$ & 113 \\
Interval between notes $(\mathrm{s})$ & 0.095 & 0.129 & 0.044 & $0.077-0.344$ & 90 \\
\hline
\end{tabular}

\section{DISCUSSION}

At the beginning of the calling activity or when individuals were isolated, simple advertisement calls (short notes only) were commonly emitted. During more intense chorus activity, with various active males at the breeding site, males emitted mostly composite advertisement calls (short and long notes). The short notes of both simple and composite calls were similar in the number of notes emitted in sequence and interval between notes, but differed in number of pulses per note, note duration, maximum, minimum, and dominant fre- quencies. We suggest that the composite advertisement call emitted by $P$. ayeaye is a mixed call, with one part possibly directed to females (short notes, advertisement) and the other directed to males (long notes, aggressiveness; see below). Male territoriality and reproductive success are often related in anurans (e.g., Wells 1977, UnSPRung et al. 2011) although the emission of aggressive territorial signals might represent energy expenditure that could be used to attract females (Wells 1988, Lingnau et al. 2004). Males of $P$. ayeaye tend to maintain territories along a stream (M.M. Borges, unpublished data); therefore, mixed calls could be an efficient strategy used by 


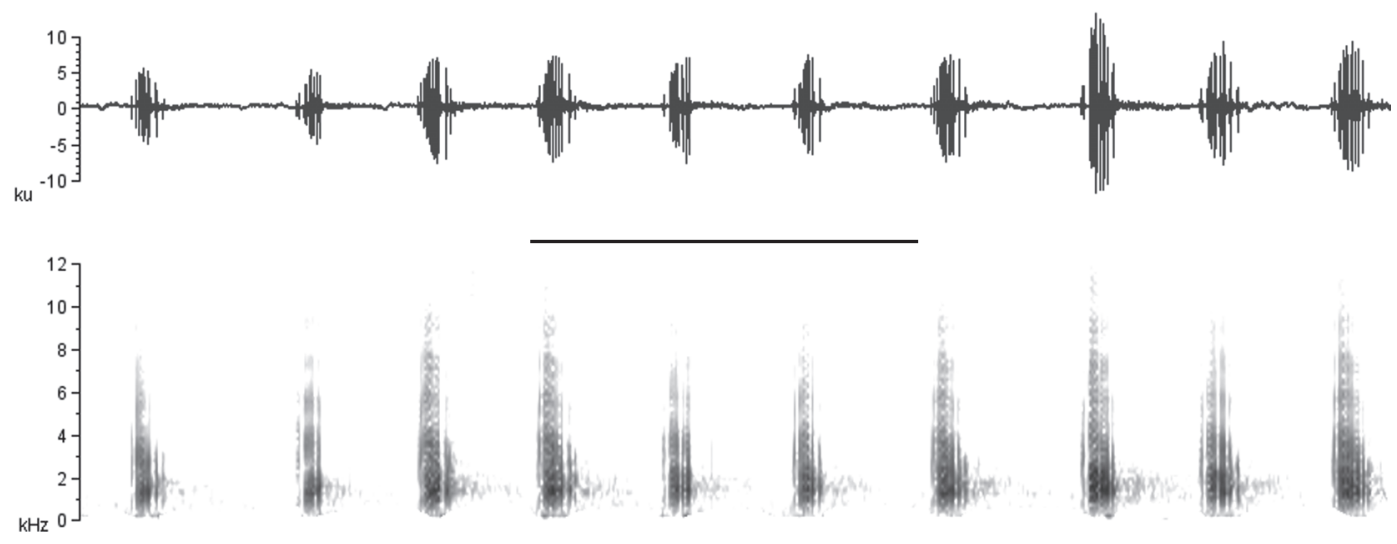

Figure 3. Sequence of Phyllomedusa ayeaye release call notes, municipality of Sacramento, southeastern Brazil (voucher specimen = $\mathrm{CFBH} 32773, \mathrm{SVL}=32.08 \mathrm{~mm}$, air temperature $=23^{\circ} \mathrm{C}$; oscillogram reading above and spectrogram below, $\mathrm{FFT}=256$, contrast $=70$, and brightness $=70$ ). The call was emitted as we simulated an axillary amplexus with our fingers. Scale bar: $0.5 \mathrm{~s}$.

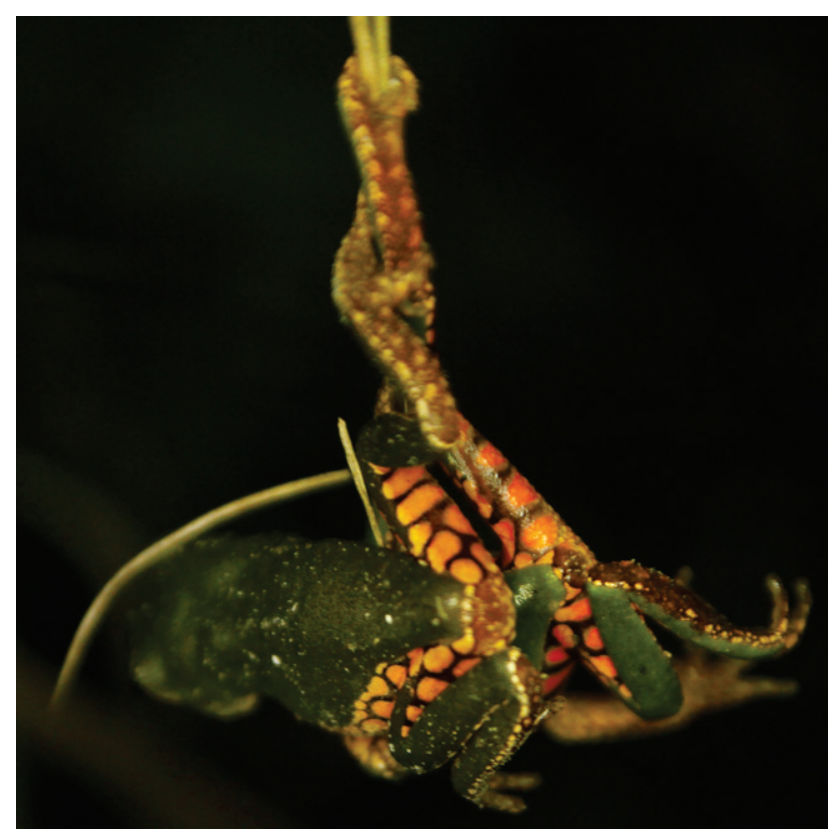

Figure 4. Physical combat between two males of Phyllomedusa ayeaye, municipality of Sacramento, southeastern Brazil (photograph by Bruno Piato).

males to convey messages related to both attracting females and enforcing territoriality between males, mainly in situations of high density (Wells 1988, Nali \& Prado 2014a).

We observed one physical combat in progress between males of $P$. ayeaye, a behavior known in other species in this genus (Abrunhosa \& Wogel 2004, Wogel et al. 2004, Costa et al. 2010, VILAÇA et al. 2011). During physical combats, male frogs may emit fighting calls sporadically (CosTA et al. 2010, NALI \& Prado 2014b, Toledo et al. 2014); thus, we may have failed to observe this type of call for this species. In addition, acoustic aggressive interactions have been reported for other congeners. For example, Phyllomedusa nordestina Caramaschi, 2006 emits a territorial call intercalated with advertisement calls (VILAÇA et al. 2011), which is very similar to the long note of the composite call described in this study for $P$. ayeaye. A similar long note was also described for Phyllomedusa centralis Bokermann, 1965, emitted by males as a response to playbacks (BRANDÃo et al. 2009). Males of $P$. ayeaye did not emit long notes alone, but always after a sequence of short notes (Fig. 3); these composite calls were observed 1) without our interference, 2) when we acoustically stimulated a resident male, and 3) when we placed an intruder male next to a resident male, in which case they emitted less short notes and more long notes to each other. Thus, we suggest that in P. ayeaye (1) the long note of the composite advertisement call is probably aggressive and directed to males and (2) this type of note might be a part of a mixed advertisement call, and not an aggressive call itself. We encourage further systematic experiments using acoustic and visual stimulation on males to confirm social functions of notes, and to test whether their variables can change in escalated aggressive interactions (e.g., Martins \& Haddad 1988, Nali \& Prado 2014a).

Release call descriptions are scarce compared to those of advertisement calls (ToLEDo et al. 2014). The release call of $P$. ayeaye was composed of short pulsed notes, which are similar to those of the advertisement calls. However, the average interval between notes was shorter than that of the advertisement calls, and spectral variables showed greater variation, with a wider spectrum of frequencies (Table 2). Short pulsed notes are also characteristic of the release call of Phyllomedusa rohdei Mertens, 1926, similar to its territorial call type 1, but with lower intensity (Wogel et al. 2004). Release calls composed of short pulsed notes may represent a shared phylogenetic trait because both species belong to the $P$. hypochondrialis group (Faivovich et al. 2010); however, a greater number of studies of 
this type of call are necessary. Besides phyllomedusines, the release call of the hylid Hypsiboas goianus (Lutz, 1968) showed harmonic structure similar to the advertisement call, although some acoustic variables differed on average from those of the advertisement and aggressive calls (DiAs et al. 2014). The release call of the toad Rhinella jimi (family Bufonidae) was composed of several randomly spaced and distributed notes, with variable amplitude and dominant frequency similar to its advertisement call (GARDA et al. 2010). In addition to what we found for $P$. ayeaye, these examples highlight a number of similar traits between release and advertisement calls, which strengthens the idea that the advertisement calls of anurans may have originally evolved from simple release signals (RAND 1988, Schmid et al. 1990).

Descriptive aspects of natural history are crucial to investigate the relationship among species and evolution of anuran reproductive behavior (GERHARDT 1994, FAIVOVICH et al. 2010). Herein, we described the calling repertoire of $P$. ayeaye, which will be useful to support its synonymization with $P$. itacolomi (BAÊTA et al. 2009). We provided evidence of acoustic aggressive interactions and the first observation of male physical combat for this species, supporting the hypothesis that male aggressive behavior may be common in this genus (VILAÇA et al. 2011). Finally, the present study may represent a starting point for further behavioral studies on this species and other Phyllomedusa species that have had their calls described, but not rigorously classified (sensu Toledo et al. 2014).

\section{ACKNOWLEDGEMENTS}

We thank B.F. Fiorillo, I.A. Martins, the editors and two anonymous reviewers for the comments on this manuscript; B.F. Fiorillo, D. Baêta, B. Piato, D.B. Delgado, C.M. Mazzarelli and L. Cholak for help with fieldwork; Neotropical Grassland Conservancy for the field equipments. R.C. Nali received graduate fellowships from the Conselho Nacional de Desenvolvimento Científico e Tecnológico (CNPq proc. 130737/2010-0) and the São Paulo Research Foundation (FAPESP proc. 2010/03656-6 and proc. 2012/06228-0). M.M. Borges received a graduate fellowship from the CNPq (proc. 130278/2013-0). C.P.A. Prado is CNPq research fellow (proc. 301125/2013-9), and received grants from CNPq (proc. 471106/2010-0) and the São Paulo Research Foundation (FAPESP proc. 2009/12013-4). Capture of individuals was authorized by the Chico Mendes Institute for Biodiversity Conservation (ICMBio, permit 19269-1).

\section{LITERATURE CITED}

Abrunhosa PA, Wogel H (2004) Breeding behavior of the leaffrog Phyllomedusa burmeisteri (Anura, Hylidae). AmphibiaReptilia 25: 125-135

Bateta D, Caramaschi U, Cruz CA, Pombal-Jr JP (2009) Phyllomedusa itacolomi Caramaschi, Cruz \& Feio, 2006, a junior synonym of Phyllomedusa ayeaye (B. Lutz, 1966) (Hylidae, Phyllomedusinae). Zootaxa 2226: 58-65.

Bastos RP, HadDaD CFB (1995) Vocalizações e interações acústicas de Hyla elegans (Anura, Hylidae) durante a atividade reprodutiva. Naturalia 20: 165-176.

BOgert CM (1960) The inûuence of sound on the behavior of amphibians and reptiles, p. 137-320. In: LANYON WE, TAVOLGa WN (Eds.). Animal sounds and communication. Washington, D.C., AIBS.

Brandão RA, Álvares GFR, Crema A, Zerbini GJ (2009) Natural history of Phyllomedusa centralis Bokermann, 1965 (Anura: Hylidae: Phyllomedusinae): Tadpole and calls. South American Journal of Herpetology 4: 61-68.

Brunetti AE, Taboada C, Faivovich J (2015) Extended vocal repertoire in Hypsiboas punctatus (Anura: Hylidae). Journal of Herpetology 49: 46-52.

Caramaschi U, Cruz CaG, Lima R, Brandão R (2010) Phyllomedusa ayeaye. In: IUCN (Ed.). The IUCN Red List of Threatened Species. Version 2014.3. Available online at: http:// www.iucnredlist.org [Accessed: 13/2/2012]

Costa TB, Guimarães LDA, Bastos RP (2010) Territorial and mating behavior in Phyllomedusa azurea (Anura: Hylidae) at a temporary pond in west-central Brazil. Phyllomedusa 9: 99-108.

Dias TM, Bastos RP, Siqueira MN, Morais AR (2014) The release call of Hypsiboas goianus (B. Lutz, 1968) (Anura: Hylidae) from Central Brazil. Herpetology Notes 7: 215-217.

DieTz JM (1984) Ecology and social organization of the maned wolf (Chrysocyon brachyurus). Smithsonian Contributions to Zoology 392: 1-51.

Faivovich J, Haddad CFB, Baêta D, Jungfer KH, Álvares GFr, Brandão RA, Sheil C, Barrientos LS, Barrio-Amoros CL, Cruz CAG, Wheeler WC (2010) The phylogenetic relationships of the charismatic poster frogs, Phyllomedusinae (Anura, Hylidae). Cladistics 26: 227-261.

Frost DR (2015) Amphibian Species of the World: an Online Reference. New York, American Museum of Natural History, Version 6.0. Available online at: http://research.amnh.org/ herpetology/amphibia/index.html. [Accessed: 8/6/2015]

Garda AA, Pedro VAS, Lion MB (2010) The advertisement and release calls of Rhinella jimi (Anura, Bufonidae). South American Journal of Herpetology 5: 151-156.

Gerhardt HC (1992) Multiple messages in acoustic signals. Seminars in Neuroscience 4: 391-400.

GerhaRdT HC (1994) The evolution of vocalization in frogs and toads. Annual Review of Ecology, Evolution, and Systematics 25: 293-324.

Giovanelli RGJ, Araujo CO, Haddad CFB, Alexandrino J (2008) Modelagem do nicho ecológico de Phyllomedusa ayeaye (Anura: Hylidae): previsão de novas áreas de ocorrência para uma espécie rara. Neotropical Biology and Conservation 3: 59-65.

Grenat PR, Martino AL (2013) The release call as a diagnostic character between cryptic related species Odontophrynus 
cordobae and O. americanus (Anura: Cycloramphidae). Zootaxa 3635: 583-586.

ICMBıo (2014) Lista de Espécies Ameaçadas. Brasília, Instituto Chico Mendes. Available online at: http://www.icmbio.gov.br/ portal/biodiversidade/fauna-brasileira/lista-de-especies.html. [Accessed: 10/2/2015]

Lea J, Dyson M, Halliday T (2001) Calling by male midwife toads stimulates females to maintain reproductive condition. Animal Behavior 61: 373-77.

Lesbarrères D, Lodé T (2002) Variations in male calls and response to an unfamiliar advertisement call in a territorial breeding anuran, Rana dalmatina: evidence for the "dear enemy" effect. Ethology Ecology \& Evolution 14: 287-95.

Lingnau R, Guimarães LD, Bastos RP (2004) Vocalizações de Hyla werneri (Anura, Hylidae) no sul do Brasil. Phyllomedusa 3 : 115-120.

Martins IA, Jim J (2003) Bioacoustic analysis of advertisement call in Hyla nana and Hyla sanborni (Anura, Hylidae) in Botucatu, São Paulo Brazil. Brazilian Journal of Biology 63: 507-516.

Martins M, Haddad CFB (1988) Vocalizations and reproductive behaviour in the smith frog, Hyla faber Wied (Amphibia: Hylidae). Amphibia-Reptilia 9: 49-60.

McDiarmid RW (1994) Preparing amphibians as scientific specimens, p. 289-297. In: Heyer WR, Donnelly MA, McDiarmid RW, Hayek LC, Foster MS (Eds.). Measuring and monitoring biological diversity. Standard methods for amphibians. Washington, D.C., Smithsonian Institution.

NALI RC, Prado CPA (2014a) Complex call with different messages in Bokermannohyla ibitiguara (Anura, Hylidae), a gladiator frog of the Brazilian Cerrado. Journal of Herpetology 48: 407414.

Nali RC, Prado CPA (2014b) The fight call of Bokermannohyla ibitiguara (Anura: Hylidae): first record for the genus. Salamandra 50: 181-184.

Penna M, Veloso A (1982) The warning vibration of Pleurodema thaul. Journal of Herpetology 16: 408-410.
RAND AS (1988) An overview of anuran acoustic communication, p. 415-431. In: Fritzsch B, Ryan MJ, Wilczynski W, Hetherington TE, WALKOWIAK W (Eds.). The evolution of the amphibian auditory system. New York, Wiley.

Ribeiro MC, Metzger JP, Martensen aC, Ponzoni FJ, Hirota MM (2009) The Brazilian Atlantic Forest: How much is left, and how is the remaining forest distributed? Implications for conservation. Biological Conservation 142: 1141-1153.

Schmidt RS, Kemnitz CP, Hudson WR (1990) Origin of anuran calling: description of toad releasing. Journal of Experimental Zoology 254: 338-342.

Silva JMC, Bates JM (2002) Biogeographic patterns and conservation in the South American Cerrado: a tropical savanna hotspot. BioScience 52: 225-233.

Toledo LF, Martins IA, Bruschi DP, Passos MA, Alexande C, Haddad CFB (2014) The anuran calling repertoire in the light of social context. Acta Ethologica 2014: 1-13.

Ursprung E, Ringler M, Jehle R, Hödl W (2011) Strong male/ male competition allows for nonchoosy females: High levels of polygynandry in a territorial frog with paternal care. Molecular Ecology 20: 1759-1771.

Vilaça TRA, Silva JRS, Solé M (2011) Vocalization and territorial behaviour of Phyllomedusa nordestina Caramaschi, 2006 (Anura: Hylidae) from southern Bahia, Brazil. Journal of Natural History 45: 1823-1834.

Wells KD (1977) Territoriality and mating success in the green frog (Rana clamitans). Ecology 58: 750-762.

WelLS KD (1988) The effects of social interactions on anuran vocal behavior, p. 433-454. In: FritZSCH B, RYAN MJ, WILCZYNSKI W, Hetherington TE, Walkowiak W (Eds.). The Evolution of the Amphibian Auditory System. New York, Wiley.

WeLLS KD (2007) The ecology and behavior of amphibians. Chicago, University of Chicago.

Wogel H, Abrunhosa P, Pombal-Jr JP (2004) Vocalizations and aggressive behavior of Phyllomedusa rohdei (Anura, Hylidae). Herpetological Review 35: 239-243.

ZAR J (1999) Bioestatistical Analyses. New Jersey, Prentice Hall.

Submitted: 20 February 2015

Received in revised form: 11 June 2015

Accepted: 19 June 2015

Editorial responsibility: Darren Norris 